\title{
Effects of gas flaring on rainwater quality in Bayelsa State, Eastern Niger-Delta region, Nigeria
}

\author{
E. E. Ezenwaji ${ }^{1}$, A. C. Okoye ${ }^{2}$ and V. I. Otti ${ }^{3 *}$ \\ ${ }^{1}$ Department of Geography and Meteorology, Nnamdi Azikiwe University, Awka, Nigeria. \\ ${ }^{2}$ Department of Environmental Management, Nnamdi Azikiwe University, Awka, Nigeria. \\ ${ }^{3}$ Department of Civil Engineering, Federal Polytechnic, Oko, Nigeria.
}

Accepted 18, May, 2013

\begin{abstract}
The aim of the paper was to study the spatial effects of gas flaring on rainwater quality in Bayelsa State, Eastern Niger-Delta, Nigeria. The physicochemical variables were isolated from the analysis of rainwater samples from eight locations in the State, while mean monthly rainfall data for 2011 of the selected areas was collected from the Port Harcourt International Airport which has a distance of 15 $\mathrm{km}$ to the farthest location and $6 \mathrm{~km}$ to the nearest location. The analysis of physicochemical elements was variously done using the relevant methods. The result shows that all the eight physicochemical elements have values above the World health Organisation (WHO) 2004 maximum allowable concentration level, but in varying degrees with $\mathrm{NO}_{3}^{-}$achieving the highest. Pearson's product moment correlation was employed to establish relationship between the eight variables and the quantity of gas flaring in the area, then principal component analysis (PCA) was utilized to collapse the eight variables into significant and orthogonal components. After these two analyses, the principal component regression (PCR) analysis was used to calculate the relative contributions of the physicochemical variables with $\mathrm{NO}_{3}$ contributing the highest of $38.44 \%$ to poor quality of rain water in the area, while temperature contributed the least of $0.19 \%$. After the PCR calculation of the entire State, it was further performed in individual locations. Result showed that all local government areas in South-West zone of the State have high rate of nitric acid accumulation in rainwater sample with those in the central zone having average rate of accumulation, while those in north-western zone exhibiting a low rate. Conclusions were drawn from the result while the major recommendation was on the need to develop a home grown gas flaring policy option that will address the problem.
\end{abstract}

Key words: Eastern, Delta, analysis, elements, rainfall.

\section{INTRODUCTION}

Gas flaring is an unavoidable part of the petroleum process confirming that there is hardly any oil producing nation which do not flare some percentage of her gas. However, statistics from various countries show that none of the affected countries flares as much quantity of gas as Nigeria. Atevure (2004) gave statistics of the percentage of gas flaring in some known world producers of oil. According to him, Libya for instance flares about $21 \%$ of its natural gas, while Saudi Arabia, Canada and
Algeria flare 20, 8 and $5 \%$ respectively, conversely Nigeria flares over $90 \%$ of its gases.

Since after the Nigerian Civil War (1967 to 1970), considering this level of flaring there had been continuous concern by Nigerians over the ways the gases are flared in the Niger-Delta region (Enehero, 1973; Aggrey 1983; Obadina, 2000; Oghifo, 2001). Olukoya (2008) noted that Nigeria is the world's biggest flarer of Associated Gas (AG) with more than 1,000 gas flaring points that release 
over 23 billion $/ \mathrm{m}^{3}$ of gas per annum. Surprisingly, notwithstanding this magnitude of flaring, over $80 \%$ are not recovered (Evo, 2002). Since the discovery of oil in Nigeria, particularly in the Niger-Delta region in 1956 at Oloibiri, Enete and Ijioma (2011) noted that gas has constantly been flared in Nigeria, polluting the Niger Delta environment. This is indeed serious, because of the large deposit of gas estimated at 120 trillion cubic feet which made Nigeria the ninth largest concentration in the world (Atevure, 2004). The deleterious effect of gas flaring on the environment is wide and varied. For example Abube (1988) noted that gas flaring destroys the aquatic environment, Okezie (1989) investigated its effect at Izombe field on the growth potentials, productivity and yield of selected farm crops and established that heat radiation results in micro bacteria decline of the affected areas which gives rise to poor farm yields.

Recent studies have investigated the impact of gas flaring on micro-climate and vegetation in which their findings indicate that over 10 hectares of vegetal land were destroyed in the area in 1998 (Odilison, 1999; Efe, 2003), on soil, air and water quality; the results show that virtually all rivers in the area are polluted (Ekanem, 2001), This is same with plant growth and vegetation in general (Dengimo, 2008; Abara, 2009). Some authors have closely associated gas flaring to the increasing poverty in the affected communities. For example Uge (2009) established a correlation between the quantity of gas flared and poverty level in Otakeme area of Bayelsa State and concluded that a strong positive correlation of 0.60 existed between the two variables. It is, however, no longer surprising that the long political agitation in the Niger-Delta region is largely attributable to the environmental degradation of oil exploitation which gas flaring is a major component. Gas flaring results in acid rain within the flared micro environment. This has been extensively discussed by Adesanya (1984), Odjugo (2002), Efe (2002), and Ogunkoya and Efe (2003), and its effect on rainwater resources have been extensively investigated in the Western Niger-Delta region (Efe, 2002; Efe et al., 2005; Rim-Rukeh et al., 2005; Lawan, 2010), but the degree and geographical extent of gas flaring on rainwater in the eastern parts of the Niger-Delta region has remained relatively scanty. This paper, therefore, seeks to examine the effects of continuous gas flaring on rainwater in Bayelsa State, Eastern Niger Delta which is one of the largest gas flaring areas in the country. The result of the paper will enable relevant government authorities to appreciate the magnitude of the flaring in the area and ensure that many laws already in place to address the problem are properly enforced.

\section{MATERIALS AND METHODS}

\section{Area of study}

Bayelsa State is situated in eastern Niger Delta region located between latitudes $04^{\circ} 15^{\prime} \mathrm{N}$ and $05^{\circ} 23^{\prime} \mathrm{N}$ and between longitudes longitudes $05^{\circ} 22^{\circ} \mathrm{E}$ and $06^{\circ} 45^{\circ} \mathrm{E}$. It is one of the major oil producing States in Nigeria contributing over $40 \%$ of the daily production in the country. It has 17 on-shore oil flow stations which flare an average of $800,00 \mathrm{~m}^{3}$ of gas per day for each of the stations and a total of $13,700,000 \mathrm{~m}^{3}$ of gas per day for the entire state (Bayelsa State Government, 2010). It is one of the six States that make up the south-south geopolitical region of Nigeria and has boundaries with Rivers State in the east, Delta State in the west and Gulf of Guinea in the south. It has a total land area of 9,059 $\mathrm{km}^{2}$ with a population density of 188 persons $/ \mathrm{km}^{2}$ (Bayelsa State Government, 2008). The state is drained by so many rivers which are at their advanced stage and such rivers include Orashi which forms the State's eastern border with Rivers State, Nun which forms the western border with Delta State, Apoi and Kugba and numerous creeks which drain the state's hinterland. Vegetation is mainly the mangrove and salt water swamps, but a major part had largely been destroyed by oil exploration. Annual rainfall amounts range from $2,500 \mathrm{~mm}$ in the northern parts of the State to $4,000 \mathrm{~mm}$ in its southern areas (Olowoyo, 2011), while mean temperature is generally $28.0^{\circ} \mathrm{C}$. The State has eight local government areas (LGAs), namely; Brass, Ekeremor, Kolokuma/Opukuma, Nembe, Ogbia, Sagbama, Southern ljaw and Yenogoa and has developed in many sectors since its creation in October 1, 1996 (Bayelsa State Government, 2008).

\section{Data collection}

Water samples for this study were collected from rainwater at the beginning of the rainy season in all the eight LGAs of the state between March and May, 2012 as this was the time when gaseous impurities in the air reached their highest concentration having not been optimally removed by the rainwater on account of the dry season that lasted for some months. The first major rainfall was recorded in most of these areas between February 24 and 28, 2012, but our water samples were collected from the middle of March, 2012 to allow impurities to be removed by the early rains. The method used in collecting the water samples followed that employed by Okoye et al. (2011) in which free fall rainwater was collected with a rainfall collector mounted on a support $1.5 \mathrm{~m}$ above the ground to avoid rain splashing effect. The funnel of the collector was filled with fibre to screen out inserts and trap debris. The rainwater samples were stored for not more than $24 \mathrm{~h}$ at a temperature of about $4^{\circ} \mathrm{C}$ in a refrigerator prior to analysis. Mean monthly rainfall amounts of the area were collected from the nearby Port Harcourt International Airport.

\section{Data analysis}

\section{Physicochemical analysis}

The analysis was done to determine the level of atmospheric pollutants, mainly temperature $\left(\mathrm{T}^{\circ} \mathrm{C}\right)$, total dissolved solids (TDS), conductivity, nitric acid $\left(\mathrm{NO}_{3}{ }^{-}\right)$, sulphuric acid $\left(\mathrm{SO}_{4}{ }^{2-}\right)$, carbonic acid $\left(\mathrm{CO}_{3-}\right)$, lead $(\mathrm{pb})$, and $\mathrm{pH}$ level. Some unstable parameters such as temperature, $\mathrm{pH}$ and conductivity were determined on the spot, using thermometer and $\mathrm{pH}$ metre (Jenway model No 3520) and conductive metre (Jenway model No. 470), respectively. The concentration of $\mathrm{Pb}$ and iron (Fe) in the water samples were determined with atomic absorption spectrophotometer (AAS). The wave lengths used for measuring were $217.0 \mathrm{~nm}$ for $\mathrm{Pb}$ and 204 $\mathrm{nm}$ for $\mathrm{Fe}$. The investigation of chemical parameters $\left(\mathrm{CO}_{3}, \mathrm{NO}_{3}{ }^{-}\right.$, $\mathrm{SO}_{4}{ }^{2-}$ ) were done using a range of techniques including AAS methods (APHA, 1992), while electrical conductivity was measured with a conductivity meter which gave the readings directly in microsiemens per centimetre $\left(\mu . \mathrm{Scm}^{-1}\right)$ at $25^{\circ} \mathrm{C}$. The conductivity metre ( $\mathrm{K}$ constant $=0.1$ ) was standardised from time to time using 
stand solutions.

\section{Statistical analysis}

The major statistical techniques employed were Pearson's product moment correlation technique to establish relationships between the eight physicochemical parameters associated with the quantity of gas flaring in the area. Principal component analysis (PCA) was utilized to collapse the eight variables into significant and orthogonal components while principal component regression (PCR) was employed to develop the regression model that would have stable coefficients. It is necessary to state that the use of PCA and PCR arose as a result of the severe autocorrelation noticed in our data. All the statistical analyses were performed with the aid of Statistical package for social sciences (SPSS) version 20 running on Windows PC.

\section{RESULTS AND DISCUSSION}

The result of the physicochemical and statistical analysis is presented in Tables 1 to 3 . The inconsistence units in which various parameters were recorded were standardized by the model for the PCA and PCR analysis.

The relationship between the eight physicochemical parameters which were the result of gas flaring and rain water in Bayelsa State was established with the use of Pearson's product moment correlation technique. The result of the statistics is presented in Table 3.

Table 3 reveals a high association between some variables as well as serial autocorrelation as many factors show strong and significant positive correlation with each order. For example $X_{1}$ (temp) is strongly and positively correlated with $\mathrm{X}_{2}(\mathrm{~Pb})(0.69)$, same for $\mathrm{X}_{1}\left(\right.$ Temp) and $\mathrm{X}_{8}$ $(\mathrm{pH})(0.72), \mathrm{X}_{3}$ (Condu) and $\mathrm{X}_{2}(\mathrm{~Pb})(0.60)$ and $\mathrm{X}_{4}$ (TDS) (0.66). Furthermore, $X_{4}$ (TDS) is very highly correlated with $\mathrm{X}_{3}$ (Cond.), then $\mathrm{X}_{5}\left(\mathrm{NO}_{3}\right)$ with $\mathrm{X}_{8}(\mathrm{pH})(0.74)$. Same for $\mathrm{X}_{6}\left(\mathrm{CO}_{3}\right)$ and $\mathrm{X}_{8} \mathrm{pH}(0.81), \mathrm{X}_{7}\left(\mathrm{SO}_{4}\right)$ and $\mathrm{X}_{8}(\mathrm{pH})$ $(0.88)$. With these very serious autocorrelations that characterized our data, there was no other alternative than to subject our correlation result to PCA, so as to transform them into defined orthogonal components that can be employed further for PCR. When PCA was transformed, the primacy of two components manifested (Table 4). Varimax rotation however maximizes the covariance of loadings on each component in order to achieve as many high and as many low loadings as possible while maintaining the orthogonality (that is, the uncorrelation) of the original component.

The two aforementioned components provided more information on the variables as well as exhibit high stability of the variables and were therefore used to perform the Multiple Regression Analysis (MRA). Component I stood out clearly in this regard and was therefore selected. The use of the values of the variables achieved by the PCA for the performance of PCR was to ensure that the variables are as orthogonal as possible so as to make their coefficients are strong, thereby ensuring that unnecessary interference or 'noise' arising from severe autocorrelation is highly minimized or completely removed. This calculation which was done for the entire State was extended to each of the eight LGAs for us to ascertain their spatial disposition. The result for the entire state is as follows:

$\mathrm{Y}=286.4-1.88 \mathrm{X}_{1}+047 \mathrm{X}_{2}-0.76 \mathrm{X}_{3}+1.02 \mathrm{X}_{4}+5.64 \mathrm{X}_{5}+$ $3.02 X_{6}+4.1 X_{7}-2.60 X_{8}(1)$

From Equation 1, it was revealed that the combined contribution of the independent variables to the overall variation was $91.6 \%$. The significance of each parameter in the model was formulated and the result presented in Table 5.

Analysis of variance (ANOVA) was further performed to determine the adequacy or otherwise of the formulated model (Table 6) usually, the p-value less than 0.05 indicates the adequacy of the model while the contrary means that the model is inadequate. When the model is inadequate, it goes to explain that it cannot sufficiently explain the variations in the dependent variable. In this analysis, our model offered a good explanation of the dependent variable. This is because in Table 6, the $p$ value is less than 0.05 which implies that the model can adequately explain variation in the dependent relationship between the amount of monthly rainfall and the eight physicochemical variables.

To determine the relative importance of the physicochemical variables, successive values of the multiple correlation coefficients were calculated by introducing successive independent variables at each computation that is, Ry. $X_{1}$, Ry. $X_{1}, X_{2}$, Ry. $X_{1}, X_{2}, X_{3}$, etc. The difference between the squared multiple correlations $\left(R^{2}\right)$ are regarded as the contribution of each variable.

Table 7 shows the relative contribution of the variables to poor rainwater quality in Bayelsa State.

The earlier calculation was repeated for each of the eight locations used in the study and the result is presented in Table 8. Bivariate Linear Regression (BLR) analysis performed between the mean amount of monthly rainfall and nitric acid which is the most important variable for each of the eight sample locations (towns) shows a startling revelation

\section{DISCUSSION}

Table 2 shows that the level of concentration of all the analysed physicochemical parameters were above the WHO maximum allowable level, but the worse affected are the nitric acid, carbonic acid and sulphuric acids which show marked concentration above the maximum standard required. This result supported the long view held by the villagers in Niger Delta that gas flaring was damaging their health, reducing their crop production and destroying their homes. Edem (2011) noted that in 2010, 
Table 1. Physicochemical parameters employed in the analysis.

\begin{tabular}{lllc}
\hline Label & $\begin{array}{l}\text { Unit of } \\
\text { measurement }\end{array}$ & Description & $\begin{array}{c}\text { Max. allowable } \\
\text { concentration (WHO, 2004) }\end{array}$ \\
\hline $\mathrm{X}_{1}(\mathrm{Temp})$ & ${ }^{\circ} \mathrm{C}$ & Average temperature of water for the period of data collection & 32.5 \\
$\mathrm{X}_{2}(\mathrm{pb})$ & $\mathrm{mg} / \mathrm{L}$ & Presence of lead in water & 0.10 \\
$\mathrm{X}_{3}(\mathrm{condu})$ & $\mu \mathrm{s} / \mathrm{cm}$ & Level of conductivity & 1000 \\
$\mathrm{X}_{4}(\mathrm{TDS})$ & $\mathrm{mg} / \mathrm{L}$ & Level of solid content in water & 500 \\
$\mathrm{X}_{5}\left(\mathrm{NO}_{3}{ }^{2-}\right)$ & $\mathrm{mg} / \mathrm{L}$ & Level of nitric acid in water & 30 \\
$\mathrm{X}_{6}\left(\mathrm{CO}_{3}\right)$ & $\mathrm{mg} / \mathrm{L}$ & Content of carbonic acid in water & 600 \\
$\mathrm{X}_{7}\left(\mathrm{SO}_{4}{ }^{2-}\right)$ & $\mathrm{mg} / \mathrm{L}$ & Presence of sulphuric acid in water & 500 \\
$\mathrm{X}_{8}(\mathrm{pH})$ at $25^{\circ} \mathrm{C}$ & $\mathrm{units}$ & Acidity or alkalinity level in water & $6.5-9.2$ \\
$\mathrm{X}_{\mathrm{g}}(\mathrm{Amount})$ & $\mathrm{mm}$ & Quantity of water collected & - \\
\hline
\end{tabular}

$X_{8}$ is the total quantity of water collected during the field work which was used as the dependent variable in the regression analysis, while physicochemical parameters where employed as the dependent variable.

Table 2. Laboratory result of rainwater in Bayelsa State.

\begin{tabular}{lccccccccc}
\hline $\begin{array}{l}\text { Sample } \\
\text { location }\end{array}$ & $\begin{array}{c}\mathbf{A m o u n t} \\
(\mathbf{m m})\end{array}$ & $\begin{array}{c}\mathrm{Temp} \\
\left({ }^{\circ} \mathbf{C}\right) \mathbf{X}_{\mathbf{1}}\end{array}$ & $\begin{array}{c}\mathbf{P b} \\
(\mathbf{m g} / \mathbf{L}) \mathbf{X}_{\mathbf{2}}\end{array}$ & $\begin{array}{c}\text { Condu } \\
(\boldsymbol{\mu s} / \mathbf{c m}) \mathbf{X}_{\mathbf{3}}\end{array}$ & $\begin{array}{c}\mathrm{TDS} \\
(\mathbf{M g} / \mathbf{L}) \mathbf{X}_{\mathbf{4}}\end{array}$ & $\begin{array}{c}\mathbf{N O}_{3} \\
(\mathbf{M g} / \mathbf{L}) \mathbf{X}_{\mathbf{5}}\end{array}$ & $\begin{array}{c}\mathbf{C O}_{\mathbf{3}} \\
(\mathbf{M g} / \mathbf{L}) \mathbf{X}_{\mathbf{6}}\end{array}$ & $\begin{array}{c}\mathbf{S O}_{\mathbf{4}} \\
(\mathbf{M g} / \mathbf{L}) \mathbf{X}_{\mathbf{7}}\end{array}$ & $\mathbf{p H}_{\mathbf{8}}$ \\
\hline Bessambiri & 325 & 30 & 0.49 & 61 & 501 & 46 & 640 & 586 & 5.3 \\
Ekeremor & 188 & 29 & 0.31 & 54 & 570 & 44 & 720 & 610 & 5.4 \\
Kaiama & 186 & 30 & 0.28 & 45 & 514 & 41 & 739 & 629 & 5.3 \\
Ogbia & 215 & 31 & 0.24 & 76 & 686 & 49 & 802 & 631 & 5.0 \\
Oporoma & 339 & 30 & 0.38 & 50 & 549 & 40 & 700 & 602 & 5.1 \\
Sagbama & 210 & 30 & 0.20 & 65 & 563 & 39 & 680 & 626 & 5.4 \\
Twon & 350 & 29 & 0.30 & 74 & 504 & 41 & 710 & 600 & 5.3 \\
Yenogoa & 198 & 29 & 0.30 & 51 & 558 & 40 & 704 & 644 & 5.3 \\
\hline
\end{tabular}

Table 3. Correlation matrix of physicochemical variables.

\begin{tabular}{lccccccccc}
\hline Variable & $\mathbf{X}_{1}$ & $\mathbf{X}_{2}$ & $\mathbf{X}_{3}$ & $\mathbf{X}_{4}$ & $\mathbf{X}_{5}$ & $\mathbf{X}_{6}$ & $\mathbf{X}_{\mathbf{7}}$ & $\mathbf{X}_{8}$ & $\mathbf{X}_{9}$ \\
\hline $\mathrm{X}_{1}(\mathrm{Temp})$ & 1.00 & & & & & & & & \\
$\mathrm{X}_{2}(\mathrm{~Pb})$ & $0.69^{*}$ & 1.00 & & & & & & & \\
$\mathrm{X}_{3}(\mathrm{Condu})$ & 0.02 & $0.60^{*}$ & 1.00 & & & & & & \\
$\mathrm{X}_{4}(\mathrm{TDS})$ & 0.34 & $0.66^{*}$ & $0.83^{*}$ & 1.00 & & & & & \\
$\mathrm{X}_{5}\left(\mathrm{NO}_{3}\right)$ & 0.28 & 0.20 & $0.61^{*}$ & 0.44 & 1.00 & & & & \\
$\mathrm{X}_{6}\left(\mathrm{CO}_{3}\right)$ & 0.17 & 0.36 & 0.04 & $0.64^{*}$ & 0.38 & 1.00 & & & \\
$\mathrm{X}_{7}\left(\mathrm{SO}_{4}\right)$ & 0.23 & 0.11 & 0.15 & 0.50 & 0.21 & 0.44 & 1.00 & & \\
$\mathrm{X}_{8}(\mathrm{pH})$ & $0.72^{*}$ & 0.24 & 0.08 & 0.10 & $0.74^{*}$ & $0.81^{*}$ & $0.88^{*}$ & 1.00 & \\
$\mathrm{X}_{9}$ (Amount) & 0.40 & $0.63^{*}$ & $0.81^{*}$ & 0.55 & $0.61^{*}$ & $0.66^{*}$ & 0.39 & $0.60^{*}$ & 1.00 \\
\hline
\end{tabular}

${ }^{*}$ coefficients that are significant at 0.05 level

about 2,000 persons were treated of various respiratory diseases in Ekeremor LGA, while over 20 hectares of farm land were destroyed by acid rain of that year. As already known, $\mathrm{SO}_{2}, \mathrm{NO}_{2}$, and $\mathrm{CO}_{2}$ are released during gas flaring and their presence in the atmosphere of Niger Delta were studied by Olabaniyi and Efe (2007) which made them to conclude that this resulted in high concentration values of $\mathrm{NO}_{3}{ }^{-}$and $\mathrm{SO}_{4}{ }^{2-}$ noticed in rainwater of the area. Ogunkoya and Efe (2003) findings show that acid rain caused about $30 \%$ of all respiratory diseases reported in the region and further noted that rainwater in Warri area contain over $75 \%$ of $\mathrm{SO}_{4}{ }^{2-}$ and $\mathrm{NO}_{3}{ }^{-}$. Again, 
Table 4. Varimax rotated component matrix of the variables.

\begin{tabular}{|c|c|c|c|}
\hline \multirow{2}{*}{ Variable } & \multicolumn{2}{|c|}{ Component } & \multirow{2}{*}{ Communality } \\
\hline & I & II & \\
\hline $\mathrm{X}_{1}$ (Temp) & -0.06500 & 0.11321 & 0.32011 \\
\hline $\mathrm{X}_{2}(\mathrm{pb})$ & 0.01462 & $0.95682^{*}$ & 0.84302 \\
\hline $\mathrm{X}_{3}$ (condu) & -0.18332 & -0.43018 & 0.02246 \\
\hline $\mathrm{X}_{4}(\mathrm{TDS})$ & 0.14628 & 0.05697 & 0.038864 \\
\hline $\mathrm{X}_{5}\left(\mathrm{NO}_{3}{ }^{-}\right)$ & $0.93200^{\star}$ & -0.05128 & 0.92306 \\
\hline $\mathrm{X}_{6}\left(\mathrm{CO}_{3}\right)$ & $0.88614^{\star}$ & 0.02350 & 0.95710 \\
\hline $\mathrm{X}_{7}\left(\mathrm{SO}_{4}{ }^{2-}\right)$ & $0.94661^{*}$ & 0.00649 & 0.90690 \\
\hline $\mathrm{X}_{8}(\mathrm{pH})$ & $0.96018^{*}$ & 0.04263 & 0.89550 \\
\hline $\mathrm{X}_{9}$ (Amount) & 0.3290 & $0.64600^{*}$ & 0.91033 \\
\hline Eigen value & 5.64 & 2.88 & - \\
\hline$\%$ of Variance explained & 72.8 & 25.6 & - \\
\hline Cumulative \% explained & 72.8 & 98.4 & - \\
\hline
\end{tabular}

*Highly loaded variables

Table 5. Significance of physicochemical parameters.

\begin{tabular}{lcccc}
\hline Predictor & Coefficient & Se & $\mathbf{T}$ & $\mathbf{P}$ \\
\hline Constant & 181.4010 & 6.3930 & 12.77 & 0.020 \\
$\mathrm{X}_{1}(\mathrm{Temp})$ & -0.88 & 0.1714 & 2,32 & 0.44 \\
$\mathrm{X}_{2}(\mathrm{pb})$ & 0.47 & 0.0286 & -0.76 & 0.042 \\
$\mathrm{X}_{3}(\mathrm{Condu})$ & -0.76 & 0.1516 & -0.93 & 0.039 \\
$\mathrm{X}_{4}(\mathrm{TDS})$ & 1.02 & 0.4188 & 4.41 & 0.022 \\
$\mathrm{X}_{5}\left(\mathrm{NO}_{3}{ }^{-}\right)$ & 5.40 & 0.6076 & 2.43 & 0.002 \\
$\mathrm{X}_{6}\left(\mathrm{CO}_{3}\right)$ & 7.02 & 9.4057 & 2.89 & 0.013 \\
$\mathrm{X}_{7}\left(\mathrm{SO}_{4}{ }^{2-}\right)$ & 13.1 & 11.1390 & 4.70 & 0.016 \\
$\mathrm{X}_{8}(\mathrm{pH})$ & -2.60 & 6.3262 & 2.20 & 0.48 \\
\hline
\end{tabular}

regarding $\mathrm{pH}$ values, we know that the result from all the LGAs is above the required maximum of 6.5 . Figures as high as 5.0 and 5.1 were recorded in Ogbia and Oporoma areas, both of them with very high gas flaring areas. This is however in line with the result of acid rain of 5.4 obtained in Eket in the neighbouring Akwa Ibom State. The high cases of leukaemia reported in this area are largely attributed to both the inhaling of these gases by villagers and consumption of acid infested rain water. Other parameters $X_{1}(T e m p), X_{2}(P b), X_{3}$ (Condu), and $X_{4}$ (TDS), although with somewhat high values, but are closely related to the $\mathrm{WHO}$ approved maximum desired level. The finding is in agreement with those of Igili (2006) and Abua (2010) who reported high incidence of leukaemia in Bassambiri and Ogbia areas of Bayelsa State.

In Table 3, the correlation of the physicochemical parameters with each other show that $\mathrm{X}_{5}\left(\mathrm{NO}_{3}\right), \mathrm{X}_{6}\left(\mathrm{CO}_{3}\right)$ and $\mathrm{X}_{7}\left(\mathrm{~S}_{4}\right)$ have high correlation coefficients and positively correlated with $\mathrm{X}_{8}(\mathrm{pH})$. Also, it was found that $\mathrm{X}_{1}(\mathrm{Temp})$ correlated with $\mathrm{X}_{8}(\mathrm{pH})$. These were however expected, because the heavy presence of these gases in the atmosphere combines with the rainwater to form various acids which heavily reduce the potential hydrogen in water, thereby polluting it with acid content. Our visit to the area shows that even surface river bodies contain high level of acids and in many localities the inhabitants do not have any other source of water to depend on, except on water from those acid polluted streams. The people of the area, however, know that something was wrong with the water they consume from these source, because of objectionable odour observed from them. Our investigation in Oloibiri in Ogbia area from some hospital sources show that about $26 \%$ of all the people suffer from either bronchitis or chronic coughing. These are respiratory diseases associated with acid rain (Igoniwari, 2012).

In Table 4 on PCA, we were able to establish that all the acidic substances together with $\mathrm{pH}$ loaded highly. This is an indication that the substances that are acidified are closely associated with $\mathrm{pH}$. It has been indicated earlier that this association is clearly the reason why the rainwater in the area is of poor quality even to the degree of being harmful. Again the high level of acidity in rain has corroded corrugated iron sheets in almost all houses in the state. Furthermore, the strength of these highly loaded variables have been corroborated by the high value of communality associated with them.

Table 5 shows again that the variables $\mathrm{X}_{5}\left(\mathrm{NO}_{3}{ }^{-}\right)$, $\mathrm{X}_{6}\left(\mathrm{CO}_{3}\right)$ and $\mathrm{X}_{7}\left(\mathrm{SO}_{4}^{2-}\right)$ are all strongly significant in the study area as could be revealed from their low p-value which are far less than the threshold of 0.05 . The overall strength of the model is seen in Table 6 which indicates a $p$-value of 0.021 showing that the regression model produced is very adequate in the explanation of acid rain in the area. The low residual error value of $I$ is an indication that the unexplained variables are weak, attesting to the high level of $91.6 \%$ attributed to the combined effects of 
Table 6. Result of analysis of variance.

\begin{tabular}{lccccc}
\hline Source & Df & Sum of squares (SS) & Mean square (MS) & F & P \\
\hline Regression & 8 & 21295.0 & 3042.1 & 17.36 & 0.021 \\
Residual Error & 1 & 9.8 & 170.8 & & \\
Total & 9 & 21304.9 & & & \\
\hline
\end{tabular}

Table 7. Relative contributions of the physicochemical variables.

\begin{tabular}{lccc}
\hline Variable & Multiple $\mathbf{R}$ & $\mathbf{R}^{2}$ & $\mathbf{R}^{2}$ Change \\
\hline $\mathrm{X}_{5}\left(\mathrm{NO}_{3}\right)$ & 0.620 & 0.3844 & 38.44 \\
$\mathrm{X}_{6}\left(\mathrm{CO}_{3}\right)$ & 0.790 & 0.6241 & 23.97 \\
$\mathrm{X}_{7}\left(\mathrm{SO}_{4}\right)$ & 0.845 & 0.7242 & 10.01 \\
$\mathrm{X}_{8}(\mathrm{pH})$ & 0.901 & 0.8118 & 8.70 \\
$\mathrm{X}_{2}(\mathrm{pb})$ & 0.936 & 0.8761 & 6.73 \\
$\mathrm{X}_{4}(\mathrm{TDS})$ & 0.950 & 0.9025 & 12.64 \\
$\mathrm{X}_{3}$ (Condu) & 0.960 & 0.9216 & 0.91 \\
$\mathrm{X}_{1}$ (Temp) & 0.961 & 0.9235 & 0.19 \\
- & - & - & $91.6 \%$ \\
\hline
\end{tabular}

Table 8. Spatial structure of the variables contributing to rainwater quality in Bayelsa State.

\begin{tabular}{llc}
\hline Sample site & Most important variable & Contribution (\%) \\
\hline Bessambiri & $\mathrm{X}_{5}$ (heavy presence of nitric acid in rain water) & 42.6 \\
Ekeremor & $\mathrm{X}_{7}$ (heavy presence of sulphuric acid in rain water) & 16.8 \\
Kaiamah & $\mathrm{X}_{6}$ (heavy presence of carbonate acid in rain water) & 21.5 \\
Ogbia & $\mathrm{X}_{5}$ (heavy presence of nitric acid in rain water) & 28.2 \\
Oporoma & $\mathrm{X}_{5}$ (heavy presence of nitric acid in rain water) & 38.2 \\
Sagbama & $\mathrm{X}_{8}$ (low potential of hydrogen $(\mathrm{pH}$ ) in rain water) & 13.8 \\
Twon & $\mathrm{X}_{5}$ (heavy presence of nitric acid in rain water) & 48.9 \\
Yenagoa & $\mathrm{X}_{8}$ (low potential of hydrogen $(\mathrm{pH})$ in rain water) & 18.2 \\
\hline
\end{tabular}

the explanatory variables leaving only $8.4 \%$ to be explained by variables not included in the analysis.

Furthermore, the importance of nitric acid in the rainwater was brought out clearly when considering high percentage contribution of $38.44 \%$ out of $91.60 \%$ attributed to all explanatory variables (Table 7 ). This result is in line with that obtained by earlier researchers that the nitric acid was found as the chief contaminant of rain water in Ibesikpo in Uyo region of the Niger Delta. In the area, whenever it rains, people feel a severe type of irritation and even burnt when water enters their eyes and concluded that this is a clear indication of heavy acid content in rain water.

The spatial disposition of the study is shown in Tables 8 and 9. Table 8 indicates that nitric acid is the most important rainwater contaminant out of four variables which were isolated by the model in the state. The towns where it is dominant are Bassambiri (Nembe LGA $(42.6 \%))$, Ogbia (Ogbia LGA (28.2\%)), Oporoma (Southern ljaw LGA (38.2\%)), and Twon (Brass LGA $(48.9 \%))$. A close study of the location of these towns where nitric acid is dominant show that all of them are at the south western end of the state. The percentage contribution of nitric acid in all of them is an indication that the area was heavily affected by gas flaring and nitric oxide which is regarded as the greatest contributor of acidity of rainwater is formed during lightning storms by the reaction of two common atmospheric gases, namely nitrogen and oxygen gases. In air, nitric oxide is oxidized to nitrogen dioxide $\left(\mathrm{NO}_{2}\right)$ which in turn reacts with water to give nitric acid $\left(\mathrm{HNO}_{3}\right)$. This acid dissociates in water to yield hydrogen ions and nitrate ions $\left(\mathrm{NO}_{3}{ }^{-}\right)$in a 
Table 9. Intercepts slopes and regression equation of the relationship between monthly rainfall amounts and nitric acid.

\begin{tabular}{lccc}
\hline Sample site & a (intercept) & b (slop) & Regression line equation \\
\hline Bessambiri & 288.40 & 7.86 & $\mathrm{Y}=288.4+7.8 \mathrm{x}$ \\
Ekeremor & 194.10 & 2.49 & $\mathrm{Y}=194.10+2.49 \mathrm{x}$ \\
Kaiamah & 189.92 & 1.96 & $\mathrm{Y}=189.92+1.36 \mathrm{x}$ \\
Ogbia & 223.45 & 9.02 & $\mathrm{Y}=223.45+7.02 \mathrm{x}$ \\
Oporoma & 249.16 & 8.66 & $\mathrm{Y}=249.16+8.66 \mathrm{x}$ \\
Sagbama & 184.88 & 1.89 & $\mathrm{Y}=184.88+1.29 \mathrm{x}$ \\
Twon & 320.32 & 6.34 & $\mathrm{Y}=320.32+6.34 \mathrm{x}$ \\
Yenagoa & 190.76 & 2.32 & $\mathrm{Y}=190.76+2.32 \mathrm{x}$ \\
\hline
\end{tabular}

reaction. In many streams and rivers in this area, surface water had become so acidic that fish can no longer live in them. Aggrey (2006) noted that gas flaring in the area has almost destroyed all the fishes in the water. One of the substances that causes this is nitric acid. The water samples collected from domestic sources of water supply showed that a lot of toxic ions especially $\mathrm{Al}^{3+}$ were present in them. Efe (2011) stated that it should be noted the target water quality range (TWQR) for $\mathrm{pH}$ for domestic water use is 6.5. In the Niger Delta area, water supply sources available to the residents have values far lower than TWQR value and this made it to be of low quality. Also, it was observed that a lot of water receptacles in these four areas are daily corroded on account of their reaction with acid contents of the rain. The low hydrogen potential $(\mathrm{pH})$ was observed as one of the important factors responsible for low rainwater quality in Sagbama (Sagbama LGA (13.8\%)) and Yenagoa (Yenagoa LGA (18.2\%)). In these two LGA, it was observed during field work that the submersible pumps and the borehole casing are corroded shortly after they were installed. In fact, in Yenagoa, the capital city, it was observed in Opolo Housing Estate that water supply installation do not last more than one year, because of corrosion. In another area in Yenogoa, it was observed that water supply pipe network together with metal water reservoirs were easily destroyed by the acid rain heightening the problem of water supply in the area. In areas such as Adagbabiri, Agbere, and Ebedebiri in Sagbama LGA, a lot of agricultural lands were found almost charred, because of the high acid content of the rain as revealed in the low $\mathrm{pH}$ of the area causing damage to plant leaves which slows or even stop the process of photosynthesis in plants. It was equally observed in Mile 2 Sagbama that the soil of the area looked very friable indicating that the low $\mathrm{pH}$ in the area has changed the once alluvial and fertile soil into acid soil which has affected its fertility and by extension of agricultural productivity.

The statistical model has isolated sulphuric acid in rainwater in Ekeremor as the most important variable with $16.8 \%$ contribution to the poor quality of acid rain in the area. The effect of this on the water samples in some communities in the area indicated an unacceptable water odour. The various water sources are still being used by the people for their domestic needs, a situation that has endangered the health of many in the area.

Finally, carbonic acid has been identified in Kaiama in Kolokuma/Opokuma LGA as the most important contaminant in rain water with $21.5 \%$. Some communities in the area such as Opokuma and Igbedi were heavily affected by carbonic acid. Samples of water investigated from the area showed that most water bodies in the area were now bereft of fish population, a problem that has dealt with the main occupation of the people. In fact almost every economic activity of the people impaired as crops were damaged while drinking water sources were heavily polluted.

Furthermore, the bivariate regression analysis between monthly rainfall amounts and nitric acid, the most important contaminant isolated in rain water in Bayelsa State indicated that all the towns used in the study exhibited upward trends in their nitric acid contribution to rainwater pollution in the area. In spatial terms, it could be seen that Oporoma with the coefficient of $8.66 \mathrm{mg} / \mathrm{L}$, Ogbia with $7.02 \mathrm{mg} / \mathrm{L}$ and Twon with $6.34 \mathrm{mg} / \mathrm{L}$ all in Southwest of the state possessed the steepest slopes in the analysis, showing that Oporoma has the greatest rate of nitric acid concentration by one unit increase in rainwater $(8.66 \mathrm{mg} / \mathrm{L})$, followed by Bassambiri $(7.8 \mathrm{mg} / \mathrm{L})$, Ogbia $(7.02 \mathrm{mg} / \mathrm{L})$ and Twon $(6.34 \mathrm{mg} / \mathrm{L})($ Table 8$)$. Then on the second category are Ekeremor $(2.49 \mathrm{mg} / \mathrm{L})$ and Yenagoa $(2.32 \mathrm{mg} / \mathrm{L})$, and the third group are Kaiamah $(1.36 \mathrm{mg} / \mathrm{L})$ and Sagbama $(1.2 \mathrm{mg} / \mathrm{L})$. The categorization of LGAs in the state on the level of nitric acid concentration is as follows:

(1) South Eastern Zone (highly concentrated): Southern ljaw, Ogbia, Nembe and Brass.

(2) Central Zone (averagely concentrated): Ekeremor and Yenagoa

(3) North Western Zone: Kolokuma/Opokuma and Sagbama.

This disposition of nitric acid concentration areas in Bayelsa State clearly gives a good picture of the 
geographical areas of greatest affliction where government should intervene as a matter of urgency.

\section{Conclusion}

The destruction of the environment and human health are two of the many effects of acid rain on any area. The exploitation of crude oil and its associated gas flaring which had resulted in the acid rain in the Niger Delta region of Nigeria have had a fairly long history. The agitation by the people for a safe environment had provoked many researchers in the area into investigating the extent of environmental degradation as a result of gas flaring. Bayelsa State with 17 onshore oil flow stations flares an average of $800,000 \mathrm{~m}^{3}$ of gas per day for each of these stations. The effect of this activity will undoubtedly be much on the environment. This study has indeed revealed that almost all physiochemical parameters identified are above the WHO recommended minimum level. The study was able to establish that nitric acid alone contributed $38.16 \%$ out of the combined contribution of $91.6 \%$ attributed to other eight variables. Further analysis of the spatial concentration of nitric acid on water samples revealed that areas in the south eastern parts of the state had the highest concentration, which can be explained by the fact that many of these flow stations are located there. Other areas where water samples show high concentration of nitric acid were categorized into zones. This zonation pattern should be used as a guide to establish the extent of mitigation measures that could be adopted for various zones of the state.

\section{RECOMMENDATIONS}

Based on the foregoing, the following recommendations were suggested. The formulation of a practical homegrown policy option that will comprehensively tackle the gas flaring problem in the Niger Delta should be the central measure to be adopted. It is indeed not enough to provide funds in the derivation account to the state government which have not been satisfactorily used for the purpose. However, based on the result of our investigation, the policy will address the following areas:

(1) Controlling the flared natural gas through the enforcement of laws aimed at limiting the quantity of gas to be flared by oil companies.

(2) Upstream petroleum producers that flare gas should be heavily taxed in accordance with the measure of gas flared.

(3) Tax holidays may be offered to companies that show manifest compliance to the law as an incentive.

(4) Houses and other structures to be coated with antiacidic chemicals to reduce the impact of acid on them.

(5) Government should always treat the acidified water bodies before they are consumed by the people. This can be done with the derivation funds monthly released to them as well as use the funds to help farmers in the areas of fishing and crop production.

(6) Continuous studies will be encouraged in the area to ascertain the temporal harmful effects of acid rain as well as its spatial disposition on the environment.

(7) The Niger Delta Development Commission (NDDC) should not only be involved in the provision of physical infrastructure but should be additionally meant to shoulder the responsibility of monitoring gas flaring and ensuring that oil companies comply with the provisions of the existing law in that regard.

(8) Serious regional development plan that will make use of the products of the aforementioned actions should be started as a way of improving the life of the people. Such plan will incorporate health, agricultural, commercial industrial water supply and biodiversity dimensions.

\section{REFERENCES}

Abara D (2009). "Chemical Analysis of Soil in parts of the Niger Delta". J. Environ. Chem. 2(1):28-34.

Abua T (2010). On the relationship between acid rain and the number of cases of leukaemia disease in some Niger Delta communities. Comm. Health 8:21-29.

Abube M (1988). "Gas flaring and Environmental Deterioration in parts of the western Nigeria Delta, Nigeria". J. Environ. Stud. 9(3):102111.

Aggrey MM (1983). Gas Flaring and Future life in the Niger Delta. Paper delivered at the National Conference on Petroleum Production in Nigeria, Lagos. $7^{\text {th }}-8^{\text {th }}$, October.

APHA (1992). Standard Method for the Examination of Water and Waste Water, $18^{\text {th }}$ Edition. American Public Health Association, Washington DC.

Atevure BSV (2004). Processes of Oil Production and Environmental Degradation: An Overview. J. Environ. Anal. 2(1):76-85.

Bayelsa State Government (2008). Bayelsa State, Glory of All lands.www.bayelsa.govt.ng

Edem BI (2011). Effect of gas flaring in Ekeremor area of Bayelsa State, Nigeria. J. Environ. Ecol. 3:38-51.

Efe SI (2002). Urban Warming in Nigeria Cities: The case of Warri Metropolis.' Afr. J. Environ. Stud. 3:160-168.

Efe SI (2003). "Effect of Gas Flaring on Temperature and Adjacent Vegetation in Nigeria Delta Environment”. Int. J. Environ. 1(1):91101.

Efe SI, Ogban FE, Horsfall M, Akpomonor (2005). Seasonal Variation of Physicochemical Characteristics in water resources Quality in Western Niger Delta Region, Nigeria.

Enehoro, A. (1973). Oil Production in Nigeria: Need for early reflection. Government Printer, Lagos.

Enete IC, ljioma MA (2011). "Effects of Gas Flaring on Soil Nutrients in Ekpan, Ogunu and Ekurede Itsekiri Communities, Delta State, Nigeria". Trop. Built Environ. J. 1(2):163-170.

Evo J (2002). The Initial Mistakes in Nigeria Oil Exploration: Need for a Rethink. National Light Newspaper, 1051:6.

Obadina V (2000). "Gas flaring in Nigeria: Matters Arising." Oil Exploration J. 2:181-193.

Odilison K (1999). Issues in the purification of Rainwater from Oil Exploration area. Ecol. Environ. 5(3):204 -215.

Ogunkoya OO, Efe EJ (2003). Rainfall Quality and Sources of Rainwater acidity in Warri area of the Niger Delta, Nigeria. J. Min. Geol. 39(2)125-130.

Okezie M (1989) "Water Quality of some surface Rivers in the Nigeria's Niger Delta." Environ. Health 2(2):84-91.

Okoye AC, Oluyemi EA, Oladikpo AA, Ezeonu FC (2011).

"Physicochemical Analysis and Trace Metal Levels of Rainwater for 
Environmental Pollution Monitoring in lle-lfe, South-western Nigeria”.J. Environ. Appl. Serv. 6(3):326-331.

Olabaniyi SB, Efe SI (2007). "Comparative Assessment of Rainwater and Groundwater Quality in an oil producing area: Environmental and Health Implications" J. Environ. Health Res. 6(2).

Olowoyo DN (2011). Physicochemical Characteristics of rainwater Quality of Warri axis of Delta State in Western Niger Delta region of Nigeria. J. Environ. Chem. Ecotoxicol. 3(2):320-322.

Olukoya M (2008). "Gas Flaring and the preservation of Biodiversity in the Niger Delta" in Aghabu (ed.) Environmental Issues in Niger Delta Region of Nigeria. Johnson Publishers, Lagos.
Rim-Rukah M, Ikiafa D, Okokoyo J (2005). Monitoring Air Pollution due to Gas Flaring using rainwater.

Uge T (2009). "Acid Rain Menace in Niger Delta Region of Nigeria". Ecol. Biodivers.3:71-80. 